\title{
Response of lowland rice (Oryza sativa L.) to fertilization when grown as main and ratoon crop
}

\author{
Dionesio M. Bañoc ${ }^{1 *}$ and Victor B. Asio
}

\begin{abstract}
Ratooning is widely considered as a strategy to increase lowland rice productivity. However, limited studies have yet been conducted in the Philippines that focus on the fine tuning of this technology. Thus, this study was conducted to evaluate the growth and yield response of main and ratoon crop of lowland rice (PSB Rc82) to fertilization and to assess the profitability of lowland rice production when grown as main and ratoon crop as influenced by fertilization. Both main and ratoon crop were subjected to the following treatments: $T_{0}$ - No fertilizer application (Control), $\mathrm{T}_{1}-90-60-60 \mathrm{~kg} \mathrm{ha}^{-1} \mathrm{~N}, \mathrm{P}_{2} \mathrm{O}_{5}$, and $\mathrm{K}_{2} \mathrm{O}$ (Inorganic Fertilizer), $\mathrm{T}_{2}-10$ t ha ${ }^{-1}$ Organic Fertilizer, $\mathrm{T}_{3}-5 \mathrm{t}$ ha ${ }^{-1}$ Organic Fertilizer $+45-30-30 \mathrm{~kg} \mathrm{ha}^{-1} \mathrm{~N}, \mathrm{P}_{2} \mathrm{O}_{5}$ and $\mathrm{K}_{2} \mathrm{O}$. Results revealed that application of inorganic fertilizers at the rates of 90-60-60 and 45-30$30 \mathrm{~kg} \mathrm{ha}^{-1} \mathrm{~N}, \mathrm{P}_{2} \mathrm{O}_{5}, \mathrm{~K}_{2} \mathrm{O}$ for the main and ratoon crops, respectively, significantly increased the leaf area index (LAI), number of productive tillers, weight of panicle, number of filled grains and grain yield. The combined application of organic and inorganic fertilizers produced taller plants, heavier straw yield, abundant number of productive tillers, heavy panicle and more filled grains. Plants applied with inorganic fertilizer at the rate of $90-60-60 \mathrm{~kg} \mathrm{ha}^{-1} \mathrm{~N}, \mathrm{P}_{2} \mathrm{O}_{5}, \mathrm{~K}_{2} \mathrm{O}$ for the main crop and $45-30-30 \mathrm{~kg}$ ha ${ }^{-1}$ of $\mathrm{N}, \mathrm{P}_{2} \mathrm{O}_{5}, \mathrm{~K}_{2} \mathrm{O}$ for the ratoon crop resulted in the highest net income.
\end{abstract}

Keywords: Lowland rice, Fertilization, Ratooning

\section{INTRODUCTION}

Lowland rice production in the Philippines is generally characterized by low productivity. This may be addressed through the use of high-yielding and stresstolerant cultivars, proper fertilization and water management, effective pest and disease control, and ratooning. Ratooning is a practice of growing a crop from the stubbles of the previous crop. Rice ratooning has been successfully adopted in many countries including India, Japan, USA, Brazil, Thailand, Taiwan and the

${ }^{1}$ Department of Agronomy, Visayas State University (VSU), Baybay City, Leyte

${ }^{2}$ Department of Soil Science, Visayas State University (VSU), Baybay City, Leyte

*Corresponding Author. Address: Department of Agronomy, Visayas State University (VSU), Visca, Baybay City, Leyte; Email: dionesio.banoc@vsu.edu.ph

DOI:10.32945/atr4116.2019 
Philippines. Bahar and De Datta (1977) reported that production of rice crop by ratooning is feasible. Ratooning of rice eliminates two labor-intensive operations: raising seedlings in the seedbed and transplanting in the main field. It also provides higher resource use efficiency per unit time and per unit land area (Santos et al 2011).

Studies on lowland rice have shown that the yield of the ratoon crop is lower than that of the main crop. Oad et al (2002) pointed out variation in the physiological parameters between the main and ratoon crop. For instance, the panicle development and heading are more uneven in the ratoon compared to that of the main crop. Mareza et al (2016) reported that rice ratoon responses to main crops cutting height at harvest depends on location, varieties and cultivation.

Santos et al (2011) noted that better yield of ratoon crop is possible by adopting appropriate management practices for the main and the ratoon crop. These management practices include land preparation, adequate plant density and spacing, use of appropriate cultivars, water management, application of adequate rate of fertilizers, appropriate height of cutting, and control of diseases, insects and weeds. Oad et al (2002) reported that application of nitrogen fertilizer is probably the most important nutrient management for improving the growth and yield of the ratoon crop of rice. However, this would also depend on the inherent fertility status of the soil. Other essential nutrients aside from nitrogen need to be applied in sufficient amounts if they are deficient in the soil in order to obtain a good main and ratoon crop yield.

Fertilization can be accomplished by using inorganic and organic fertilizers. The generally high nutrient contents of inorganic fertilizers make them popular among rice farmers. In recent years, however, the use of organic fertilizers has been shown to provide advantages in terms of crop yield. They are also generally cheap and locally available. The study was conducted to evaluate the growth and yield performance of lowland rice NSIC Rc82 as influenced by fertilizer application when grown as main and ratoon crop; and assess the profitability of producing lowland rice grown as main and ratoon crop under the different fertilization strategies.

\section{MATERIALS AND METHODS}

\section{Study Site}

This study was conducted at a farmers' field (irrigated lowland) in Pomponan, Baybay City, Leyte. The main crop lasted from November 15, 2015 to February 15, 2016 while the ratoon crop was allowed to grow and monitored from February 16, 2016 until April 15, 2016. An experimental area of $161.5 \mathrm{~m}^{2}$ was irrigated for 15 days and was puddled twice using hand tractor at weekly interval. After the last puddling, the paddies were divided into plots and dikes were established to control water and avoid contamination of treatments.

\section{Soil Sampling and Analysis}

Ten initial soil samples were randomly collected at a depth of about $30 \mathrm{~cm}$ from the experimental area. The collected samples were composited, air dried and sieved using $2 \mathrm{~mm}$ wire mesh and analyzed at the Central Analytical Service 
Response of lowland rice

Laboratory (CASL), PhilRootcrops, Visayas State University, Visca, Baybay City, Leyte. The samples were analyzed for soil pH (Potentiometric Method at 1:2.5 soilwater ratio, ISRIC 1995), total N (Kjeldahl Method, ISRIC 1995), organic matter (Modified Walkley-Black Method, Nelson \& Sommers 1982), available P (Olsen Method, Olsen et al 1954), and exchangeable K (ammonium acetate) extraction method using atomic absorption spectrophotometry (ISRIC 1995). For final soil analysis, three samples were collected from each treatment plot right after harvest at a depth of about $30 \mathrm{~cm}$. These were composited per treatment and analyzed for the same soil parameters mentioned above.

\section{A) Main Crop}

\section{Experimental design and field lay-out}

The experimental area was laid out in a Randomized Complete Block Design (RCBD) with three replications. Each replication was divided into four treatment plots, measuring $5 \mathrm{~m} \times 2 \mathrm{~m}$ with ten rows per treatment plot. Alleyways were provided between replications and between treatment plots, respectively, to facilitate farm operations and management as well as data gathering.

The different treatments were designated as follows:

$\mathrm{T}_{0}$ - No fertilizer application (Control)

$\mathrm{T}_{1}-90-60-60 \mathrm{~kg} \mathrm{ha}^{-1} \mathrm{~N}, \mathrm{P}_{2} \mathrm{O}_{5}$, and $\mathrm{K}_{2} \mathrm{O}$ (Inorganic Fertilizer)

$\mathrm{T}_{2}-10 \mathrm{tha}^{-1}$ Organic Fertilizer (Wellgrow)

$\mathrm{T}_{3}-5 \mathrm{t} \mathrm{ha}^{-1}$ Organic Fertilizer $+45-30-30 \mathrm{~kg} \mathrm{ha}^{-1} \mathrm{~N}, \mathrm{P}_{2} \mathrm{O}_{5}$ and $\mathrm{K}_{2} \mathrm{O}$

\section{Seedbed and seedling preparation}

An ordinary wetbed measuring $1 \mathrm{~m}$ wide and $5 \mathrm{~m}$ long with drainage canal around was constructed in a separate area to avoid obstruction in the preparation of the experimental plot. Three kg seeds of PSB Rc82 was soaked in water for $24 \mathrm{~h}$ then incubated for $48 \mathrm{~h}$ and sown in the seedbed.

\section{Transplanting}

The 20-day old seedlings of rice variety (PSB Rc82) were transplanted in the experimental area at the rate of one seedling per hill at a distance of $20 \mathrm{~cm} \times 20 \mathrm{~cm}$ between hills. Replanting of missing hills was done three to five days later.

\section{Fertilizer application}

For the inorganic fertilizer, complete (14-14-14), and urea (46-0-0) were used to satisfy the required amount of fertilizer for the inorganic fertilizer-treated plots. Basal application of complete fertilizer was done at eight days after transplanting and the remaining amount of $\mathrm{N}$ was top dressed using urea fertilizer at 40 days after transplanting. For the organic fertilizer treatment, Wellgrow (a commercial organic 
fertilizer) was applied two days before planting by incorporating it into the soil.

\section{Control of pests and diseases}

Golden apple snails (Pomacea canaliculata L.) were controlled by handpicking the snails and egg clusters. Lannate at one sachet per $16 \mathrm{~L}$ water was sprayed at milking stage to control rice bug infestation of crop plants. For the weed control, rotary and hand weeding were done at 15 days after transplanting. Thereafter, spot hand weeding was done to control weeds.

\section{Water management}

The experimental area was irrigated at a depth of $2 \mathrm{~cm}$ three days after transplanting. During the reproductive stage, the water level was increased to $5 \mathrm{~cm}$. Two weeks before harvesting, the whole area was drained to facilitate harvesting.

\section{Harvesting}

Harvesting of rice was done using a sharp sickle when approximately $85 \%$ of the grains in each plot were ripened as indicated by leaves turning to golden brown or yellow and the grains of the panicles turned firm and amber colored. All sample plants in the harvestable area $(4.2 \mathrm{~m} \times 1.6 \mathrm{~m})$ were cut at the base with a sharp sickle excluding the two border rows on each side of the plot and one hill on both ends of each row. Harvested panicles were threshed and the grains were sundried for three days and cleaned separately per treatment before data gathering.

\section{Data Gathered}

\section{A. Agronomic parameters (main crop)}

1. Number of days from sowing to maturity - This was recorded as the number of days from sowing to the time when $85 \%$ of the grains on the panicle had matured as shown by their firm and amber color.

2. Plant height $(\mathrm{cm})$ at maturity - The height from the ground level to the tip of the tallest plant part at maturity of ten sample hills in each treatment plot was measured.

3. Number of nodal roots per hill - The number of nodal roots(adventitious roots that form rings from stem tissues around a node) from the five sample plants per treatment plot at heading stage was determined. The sample was taken from the border rows through destructive sampling by uprooting the plants and washing off any loose soil.

4. Nodal root axis length per plant $(\mathrm{cm})$ - This was gathered by measuring the nodal roots axis length of five sample plants per treatment plot.

5. Root length $(\mathrm{cm})$ per plant at heading - The root length of five sample plants per treatment plot was measured from the base of the longest root until the root tip of the sample plant at heading. 
Response of lowland rice

6. Leaf area index (LAI) - This was determined at heading stage by following the procedure described by Gomez (1972).

a. Ten sample hills were randomly selected from each plot and each sample hill was surrounded by living plants,

b. The number of tillers for each sample hill was counted in each plot,

c. The main tiller was selected for measurement,

d. The length and width (broadest part) of each leaf from the main tiller of each sample hill were measured,

e. The area of each leaf was computed based on the following formula:

$$
\mathrm{LA}=\mathrm{LxWxCF}
$$

Where: $L A=$ leaf area

$\mathrm{L}=$ length of each leaf

$\mathrm{W}=$ width of each leaf measured at the broadest part

$\mathrm{CF}=$ correction factor which is equal to 0.75 (Yoshida 1981)

f. The leaf area of the leaves was added to get the total leaf area of the main

tiller,

g. The leaf area per hill was computed by following the formula given:

Leaf area/hill

h. The leaf area index (LAl) was computed based on the following formula:

$$
\mathrm{LAI}=\frac{\text { Sum of the leaf area per hill of } 10 \text { sample hills }\left(\mathrm{cm}^{2}\right)}{\text { Area of land covered by } 10 \text { sample hills }\left(4,000 \mathrm{~cm}^{2}\right)}
$$

7. Flag leaf length $(\mathrm{cm})$ - The length of flag leaf of ten sample plants was determined by measuring from the base until the tip of the leaf at heading stage.

8. Fresh straw yield ( $\left.t \mathrm{ha}^{-1}\right)$ - Rice straw was cut at the ground level and weighed without panicles. The straw yield was converted into tons per hectare using the formula:

$$
\text { Straw Yield }\left(\mathrm{tha}^{-1}\right)=\frac{\text { plot yield }(\mathrm{kg})}{\text { Harvestable area }\left(6.72 \mathrm{~m}^{2}\right)} \times \frac{10,000 \mathrm{~m}^{2} \mathrm{ha}^{-1}}{1,000 \mathrm{~kg} \mathrm{t}^{-1}}
$$

\section{B. Yield and yield component parameters (main crop)}

1. Number of productive tillers per hill - This was determined by counting the tillers that developed panicles from ten sample plants in each treatment plot and counted at ripening stage of the main crop.

2. Panicle length $(\mathrm{cm})$ at maturity - The average length of panicle was determined by measuring the length from the base up to the tip of ten sample panicles in each treatment plot.

3. Panicle weight (g) - Ten sample panicles per treatment plot were weighed and the weight was divided by ten to get the average weight of panicle.

4. Number of filled and unfilled grains per panicle - The number of filled and unfilled grains from ten sample panicles in each treatment plot of the main crop was counted. 
5. Weight (g) of 1,000 grains - This was obtained by weighing 1,000 grains taken at random from clean and dry grains obtained from each treatment plot of the main crop. The seeds were sun-dried for three days before weighing.

6. Grain yield ( $t$ ha ${ }^{-1}$ ) - This was determined by weighing the total harvested grains of the main crop obtained from harvestable area in each treatment plot. The grains were cleaned, sun-dried for three days and were converted into tons per hectare using the formula:

$$
\text { Grain Yield }\left(\text { tha }^{-1}\right)=\frac{\text { plot yield }(\mathrm{kg})}{\text { Harvestable area }\left(6.72 \mathrm{~m}^{2}\right)} \times \frac{10,000 \mathrm{~m}^{2} \mathrm{ha}^{-1}}{1,000 \mathrm{~kg} \mathrm{t}^{-1}}
$$

\section{B) Ratoon Crop}

\section{Experimental design and field layout}

The experimental area was laid out similar to the main crop and replicated three times.

\section{Fertilizer and fertilizer application}

All plots of the ratoon crop were applied with half of the rates of fertilizers indicated in the treatments for the main $\operatorname{crop}\left(T_{1}, T_{2} \& T_{3}\right)$ except $T_{0}$ which received no fertilizer application. Urea (46-0-0) was the source of $N$ fertilizer. However, phosphorus and potassium requirements were satisfied using solophos and muriate of potash and were applied 14 days after harvesting of the main crop. For the organic fertilizer, Wellgrow was used.

\section{Water management}

Water management option like continuous flooding right after harvesting of the main crop until two weeks after was done. This was followed by intermittent irrigation at two weeks thereafter.

\section{Control of pests and diseases}

Handpicking of golden apple snails (Pomacea canaliculata L.) was done in the experimental area after harvesting of the main crop. Insecticides were sprayed based on the manufacturer's recommended dosage during the reproductive growth phases of the ratoon crop to control insect pests such as stem borers, rice bugs, leaf folders among others.

A hand weeding operation was adopted to control the weeds in the experimental area at 20 days after harvesting of the main crop. Succeeding spot weeding operation was done two weeks later. The weeds around each hill were removed by hand weeding as well.

\section{Harvesting}

Using a sharp sickle, ratoon crops within the harvestable area were harvested when $85 \%$ of the grains in each treatment plot ripened and became firm. All panicles 
Response of lowland rice

in the harvestable area were threshed, cleaned, sun dried for three days and winnowed before the necessary data were gathered.

\section{Data Gathered (Ratoon crop)}

All agronomic parameters as well as yield, and yield components of ratoon crop were gathered similar to the main crop except the number of days from harvesting of the main crop to maturity of the ratoon crop as well as harvest index.

1. Days from harvesting of the main crop to maturity of ratoon crop - this was determined by counting the number of days from sowing to the time when $85 \%$ of the panicles in each treatment plot of the ratoon crop ripened as manifested by yellow and firm grains.

\section{Harvest Index (HI)}

This is the ratio of the dry weight of filled grains over the dry weight of straw, chaff, and filled grains of the ratoon plants. This parameter indicates the plant's efficiency to convert the absorbed nutrient and product of photosynthesis into grain yield in proportion to the straw yield.

Harvest index was determined by harvesting three sample hills randomly taken from each treatment plot within the harvestable area. The samples were cut close to the ground and the grains and straw were separated then air dried before ovendrying at $70^{\circ} \mathrm{C}$ for three days. Harvest index was obtained using the formula:

$$
\mathrm{HI}=\frac{\text { Economic yield }}{\text { Biological yield }}=\frac{\text { dry weight of grains }(3 \text { samples })}{\text { dry weight of grains }+ \text { dry straw yield }+ \text { chaff }}
$$

\section{Cost and Return Analysis}

The production cost was determined by recording all the expenses incurred from land preparation up to harvesting of the crop. This included labor costs incurred during organic and inorganic fertilizers application, chemical and other materials used in this study. The gross return was determined by multiplying the yield in each treatment plot by the current price of rice per kilogram. All income and expenses were computed and summed up to determine the most promising and most economical treatment. In determining the net profit, the total expenses incurred in every treatment was subtracted from the gross income using the formula:

$$
\text { Net Return }=\text { Gross Income }- \text { Total Expenses }
$$

\section{Meteorological Data}

Data on the total weekly rainfall, average minimum and maximum temperatures $\left({ }^{\circ} \mathrm{C}\right)$, and relative humidity (\%) were obtained from the Philippine Atmospheric Geophysical and Astronomical Services Administration (PAGASA) Station, Visayas State University, Visca, Baybay City, Leyte from November 21, 2015 to February 15, 2016 for the main crop and February 16, 2016 to April 15, 2016 for the ratoon crop. 
Main and ratoon crops were exposed to more than 14 and 9 weeks of growth periods, respectively. For the former crop, highest precipitation was noted in the third week of January (January 24-January 30 ) while the lowest rainfall was experienced during the first week of January. For the ratoon crop, however, plants generally were exposed to limited soil moisture which started at four weeks after harvesting of the main crop (March 08-Mar 14) until the ninth week from April $2-$ April 15,2016 . The total amount of rainfall received by the main crop and ratoon crop were $903 \mathrm{~mm}$ and $154 \mathrm{~mm}$, respectively. De Datta (198) stipulated that precipitation of $900-1,000 \mathrm{~mm}$ during the cropping season is adequate to achieve higher productivity, thereby, the amount of rainfall recorded during the main crop period was adequate while insufficient during the ratooned period. The average minimum and maximum temperatures during the main crop period were 24.2 and $31.3^{\circ} \mathrm{C}$, respectively while the ratoon crop had almost similar minimum and maximum temperatures of 24.4 and $31.8^{\circ} \mathrm{C}$, respectively. Relative humidity (RH) was $80.5 \%$ and $78.70 \%$ for the main crop and ratoon cop, respectively. $\mathrm{RH}$ data showed that these were conformed to the findings of Weerakoon et al (2008) that optimum $\mathrm{RH}$ for rice plant ranged from $60-80 \%$ that would effects normal growth and development.

\section{RESULTS AND DISCUSSION}

\section{Initial and Final Soil Nutrient Status}

Result of initial soil analysis showed that the soil had $\mathrm{pH}$ of 7.42 with $3.29 \%$ organic matter, $0.21 \%$ total $\mathrm{N}, 14.84 \mathrm{mg} \mathrm{kg}^{-1}$ available $\mathrm{P}, 0.19 \mathrm{me} 100 \mathrm{~g}^{-1}$ exchangeable $\mathrm{K}($ Table 1$)$. These results indicate that the soil was slightly alkaline, medium in organic matter, total $\mathrm{N}$, available $\mathrm{P}$ contents, and low in exchangeable $\mathrm{K}$ (Landon 1991).

Table 1. Chemical properties of the soil before planting the main crop and after harvest of the ratoon crops

\begin{tabular}{|c|c|c|c|c|c|}
\hline Sampling Period & $\begin{array}{l}\text { Soil pH } \\
(1: 2.5)\end{array}$ & $\begin{array}{c}\text { Organic } \\
\text { Matter } \\
(\%)\end{array}$ & $\begin{array}{c}\text { Total } \\
N \\
(\%)\end{array}$ & $\begin{array}{c}\text { Available } \\
P \\
\left(\mathrm{mg} \mathrm{kg}^{-1}\right)\end{array}$ & $\begin{array}{l}\text { Exchangeable K } \\
\text { (me 100 } \mathrm{g}^{-1} \text { soil) }\end{array}$ \\
\hline Initial soil analysis & 7.42 & 3.29 & 0.21 & 14.84 & 0.19 \\
\hline \multicolumn{6}{|l|}{ Final Soil Analysis } \\
\hline $\mathrm{T}_{0}=$ No fertilizer application & 7.47 & 4.11 & 0.22 & 12.64 & 0.11 \\
\hline \multicolumn{6}{|l|}{$T_{2}=90-60-60 \mathrm{~kg} \mathrm{ha}^{-1} \mathrm{~N}, \mathrm{P}_{2} \mathrm{O}_{5} \&$} \\
\hline $\mathrm{K}_{2} \mathrm{O}$ & 7.67 & 3.74 & 0.23 & 28.16 & 0.12 \\
\hline $\mathrm{T}_{3}=10 \mathrm{t} \mathrm{ha}^{-1}$ Organic Fertilizer & 7.40 & 4.28 & 0.28 & 52.48 & 0.24 \\
\hline $\begin{array}{l}T_{4}=5 t_{\text {ha }}{ }^{-1} \text { Organic Fertilizer }+ \\
45-30-30 \mathrm{~kg} \mathrm{ha}^{-1} \mathrm{~N}, \mathrm{P}_{2} \mathrm{O}_{5} \text {, and } \mathrm{K}_{2} \mathrm{O}\end{array}$ & 7.60 & 4.25 & 0.23 & 68.56 & 0.19 \\
\hline
\end{tabular}




\section{Response of lowland rice}

Final soil analysis revealed only slight changes in the fertility station of the soil except in terms of the available P content. As can be seen from the table, there was a considerable increase in the available $P$ station of the soil most probably due to the application of fertilizers.

\section{Agronomic Characteristics and Root Growth and Development of the Main Crop}

Table 2 shows the agronomic characteristics of the main crop of lowland rice (PSB Rc82) as influenced by fertilization. Results showed that the application of fertilizers significantly affected the number of days from sowing to maturity and plant height but not the leaf area index (LAI), flag leaf length and fresh straw yield. In terms of maturity period, all fertilized plants matured significantly earlier than the unfertilized control. Results also revealed that all fertilized plants were significantly taller, and have developed longer and broader leaves than the unfertilized plants. This result indicates that the application of inorganic and organic fertilizers enhanced the vegetative growth and development of the essential vegetative plant parts, resulting in earlier maturity of the treated plants compared to the unfertilized control plants. Baoy and Bañoc (2017) found that fertilized rice plants grew faster corresponding to the amount of applied nutrients received. They added that the longer and broader leaves produced were usually manifested in taller plants resulting in higher LAI than in shorter plants.

Table 2. Agronomic characteristics of the main crop of lowland rice (PSB Rc82) as influenced by fertilization

\begin{tabular}{|c|c|c|c|c|c|}
\hline Treatment & $\begin{array}{l}\text { No. of days } \\
\text { from sowing } \\
\text { to maturity }\end{array}$ & $\begin{array}{l}\text { Plant Height } \\
(\mathrm{cm})\end{array}$ & $\begin{array}{l}\text { Leaf Area } \\
\text { Index (LAI) }\end{array}$ & $\begin{array}{c}\text { Flagleaf } \\
\text { Length }(\mathrm{cm})\end{array}$ & $\begin{array}{c}\text { Straw Yield ( } t \\
\left.\text { ha }^{-1}\right)\end{array}$ \\
\hline $\begin{array}{l}\mathrm{T}_{0}-\mathrm{No} \\
\text { fertilization } \\
\text { (control) }\end{array}$ & $120.0 a$ & $63.58 b$ & 1.86 & 28.40 & 3.96 \\
\hline $\begin{array}{l}\mathrm{T}_{1}-90-60-60 \mathrm{~kg} \\
\mathrm{ha}^{-1} \mathrm{~N} \\
\mathrm{P}_{2} \mathrm{O}_{5}, \mathrm{~K}_{2} \mathrm{O}\end{array}$ & 113.0b & $78.99 a$ & 3.70 & 36.03 & 6.08 \\
\hline $\begin{array}{r}\mathrm{T}_{2}-10 \mathrm{t} \mathrm{ha}^{-1} \\
\text { Wellgrow }\end{array}$ & $113.0 \mathrm{~b}$ & $81.55 a$ & 3.95 & 31.18 & 5.94 \\
\hline $\begin{array}{l}\mathrm{T}_{3}-45-30-30 \mathrm{~kg} \\
\mathrm{ha}^{-1} \mathrm{~N} \\
\mathrm{P}_{2} \mathrm{O}_{5}, \mathrm{~K}_{2} \mathrm{O} \\
+5 \mathrm{tha}^{-1} \\
\text { Wellgrow }\end{array}$ & $113.0 \mathrm{~b}$ & $79.78 a$ & 3.30 & 33.78 & 6.67 \\
\hline
\end{tabular}

Table 3 presents the root growth and development of the main crop as influenced by fertilization. It shows that all fertilized plants regardless of fertilization treatment significantly influenced the number of nodal roots per hill. For the nodal root (NR) axis length, plants that received organic fertilizer $\left(T_{2}\right)$ significantly achieved longest NR axis length of $17.14 \mathrm{~cm}$ followed by plants with 
combined application of organic and inorganic fertilizers $\left(T_{3}\right)$ with $16.98 \mathrm{~cm}$, while those applied with inorganic fertilizers $\left(T_{1}\right)$ alone obtained only $15.79 \mathrm{~cm}$ and the unfertilized plants had the shortest nodal root axis length $(14.08 \mathrm{~cm})$. Longest root length of $29.33 \mathrm{~cm}$ was achieved by plants applied with the combination of organic and inorganic fertilizers. Root length of plants applied with organic $\left(T_{2}\right)$ and inorganic fertilizers $\left(T_{1}\right)$ were not significantly different from each other. Unfertilized plants obtained the shortest root length of $21.5 \mathrm{~cm}$. These findings suggest that the rapid growth and development of the root system particularly the production and elongation of nodal roots in the fertilized plants was influenced by fertilizer application. It may be attributed to the abundant translocation of assimilates into the root system of the fertilized plants resulting in more production of nodal roots, elongated longer root length and apparently production of longer NR axis length. On the other hand, the limited root growth and development of the root system of the unfertilized plants might be due to the decreased translocation of photosynthates to the roots (Bidwell 1974). This result conformed with the findings of Bañoc (2000) that abundant number of nodal roots and longer nodal root axis length were the strong manifestations on the ability of rice plants to alter their root physiology and morphology in response to the changing soil environment. According to Abe et al (1995) the branching degree of roots is an important factor determining the total length and surface area of roots as well as the number of nodal roots. They mentioned that rice plants to which nitrogen had been supplied continuously until the flowering stage by frequent topdressing of chemical fertilizer also formed superficial roots with well-developed lateral roots. They added that the maintenance of an adequate nitrogen content in soil at the later stage of growth caused the slow release of nitrogen from compost that promoted root branching in rice plant.

Table 3. Root growth and development of main crop lowland rice (PSB Rc82) as influenced by fertilization

\begin{tabular}{|c|c|c|c|}
\hline Treatment & $\begin{array}{l}\text { Number of Nodal } \\
\text { Roots per hill }\end{array}$ & $\begin{array}{l}\text { Nodal Root Axis Length } \\
\qquad(\mathrm{cm})\end{array}$ & Root Length (cm) \\
\hline $\begin{array}{l}\mathrm{T}_{0}-\text { - No fertilization } \\
\text { (control) }\end{array}$ & $300.22 b$ & $14.08 \mathrm{~b}$ & $21.50 \mathrm{~b}$ \\
\hline $\begin{array}{c}\mathrm{T}_{1}-90-60-60 \mathrm{~kg} \mathrm{ha}^{-1} \\
\mathrm{~N}, \mathrm{P}_{2} \mathrm{O}_{5}, \mathrm{~K}_{2} \mathrm{O}\end{array}$ & $529.89 a$ & 15.79ab & 26.28ab \\
\hline $\begin{array}{l}\mathrm{T}_{2}-10 \mathrm{tha}^{-1} \\
\text { Wellgrow }\end{array}$ & $494.89 a$ & $17.14 a$ & $26.50 \mathrm{ab}$ \\
\hline $\begin{array}{c}\mathrm{T}_{3}-45-30-30 \mathrm{~kg} \mathrm{ha}^{-1} \\
\mathrm{~N}, \mathrm{P}_{2} \mathrm{O}_{5}, \mathrm{~K}_{2} \mathrm{O}+ \\
5 \mathrm{t} \mathrm{ha}^{-1} \text { Wellgrow }\end{array}$ & $509.11 \mathrm{a}$ & $16.98 \mathrm{a}$ & $29.33 a$ \\
\hline
\end{tabular}

\section{Yield and Yield Components of the Main Crop}

Table 4 reveals that the different fertilization treatments markedly affected all the yield and yield components of the main crop except the weight of 1,000 grains. It must be noted that plants which received a combined application of organic and 
inorganic fertilizers $\left(T_{3}\right)$ had significantly higher number of productive tillers $(12.67$ tillers per hill) compared to the unfertilized control $\left(T_{0}\right)$ with only 7.55 tillers per hill. This was followed by plants applied with inorganic fertilizers at the rate of 90-60$60 \mathrm{~kg} \mathrm{ha}^{-1} \mathrm{~N}, \mathrm{P}_{2} \mathrm{O}_{5}, \mathrm{~K}_{2} \mathrm{O}\left(\mathrm{T}_{1}\right)$ with 11.67 productive tillers per hill and those treated with purely organic fertilizers $\left(\mathrm{T}_{2}\right)$ also achieved similar result that influenced the development of productive tillers with 11.33 tillers per hill.

Regarding panicle length $(\mathrm{cm})$, the main crop applied with organic fertilizer $\left(T_{2}\right)$ produced the longest panicle compared to the unfertilized plants $\left(T_{0}\right)$ and those plants that received a combination of organic and inorganic fertilizers $\left(T_{3}\right)$. This was followed by plants applied with inorganic fertilizer $\left(T_{1}\right)$ with similar effects based on statistical analysis. For the weight of panicles, however, plants that received inorganic fertilizer $\left(T_{1}\right)$ obtained the heaviest panicles as compared to all other treatments especially the unfertilized plants $\left(T_{0}\right)$. Heavier panicles were noted in plants that received fertilizers as pure organic $\left(T_{2}\right)$ or as combined of organic and inorganic fertilizers $\left(T_{3}\right)$, but they were still inferior to $T_{1}$. Findings also indicate that in terms of the number of filled grains, plants applied with inorganic fertilizer $\left(T_{1}\right)$ developed significantly higher number of filled grains with 129.8 grains per panicle than those in all other treatments evaluated (Table 4). This was followed by $T_{3}$ with 96.27 grains per panicle and by those plants applied with purely organic fertilizer $\left(T_{2}\right)$ with 87.57 grains per panicle. However, plants applied with a combination of organic and inorganic fertilizers $\left(T_{3}\right)$ and organic fertilizer $\left(T_{2}\right)$ significantly produced higher unfilled grains when compared to those that received inorganic fertilizer $\left(T_{1}\right)$ and the unfertilized control plants. On the other hand, it was observed that the unfertilized ratoon plants obtained the highest number of unfilled grains (Table 7).

In terms of grain yield, rice plants applied with inorganic fertilizer $\left(T_{1}\right)$ significantly produced higher grain yield $\left(3.52 \mathrm{t} \mathrm{ha}^{-1}\right)$ than the unfertilized plants. This was followed by plants applied with a combination of organic and inorganic fertilizers $\left(T_{3}\right)$. This result agrees with the study of Javier and Espiritu (2015) and can be attributed to the effective and efficient utilization of nutrients for the rapid growth and development of plant component parts that responded mainly in achieving high production of productive tillers, heavier and longer panicle length, and more abundant filled grains. Readily available macro nutrients (NPK) provided by the inorganic fertilizer enhanced the growth and development of rice plants that led to the production of more productive tillers, longer panicles, more filled grains, heavier grains and, consequently, higher grain yield. This result suggests that there was more translocation of photosynthates or assimilates to the grains than to the straw as shown by higher HI. This further suggests that plants not applied with fertilizer had restricted growth and development of tillers, leaves, panicles and grains resulting in limited photosynthetic source-sink relation. 
Bañoc \& Asio

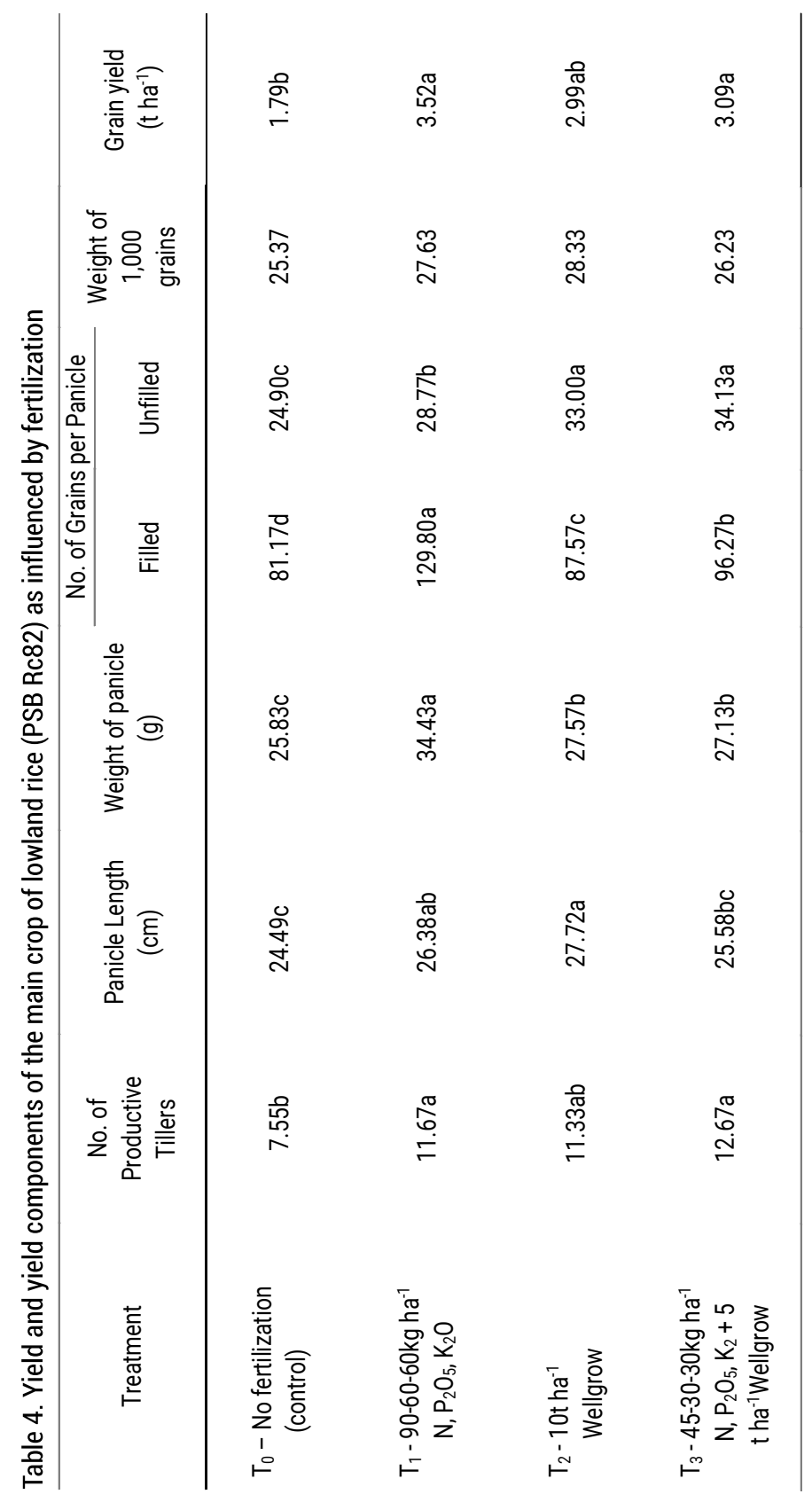




\section{Agronomic Characteristics, Root Growth and Development of the Ratoon Crop}

The agronomic characteristics of the ratoon crop as influenced by fertilization are presented in Table 5 while the root growth and development parameters are reflected in Table 6. Statistical analysis showed that all agronomic parameters of the ratoon crop were not significantly affected by fertilization except the number of days from harvesting of the main crop to maturity of ratoon crop and the total number of nodal roots (NRs) produced per hill.

Table 5 reveals that ratoon plants applied with fertilizers significantly matured earlier than the unfertilized plants. Likewise, ratoon plants that received organic fertilizer $\left(T_{2}\right)$ significantly produced higher number of nodal roots per hill (677.55 NRs per hill) than the unfertilized plants with only 420.78 NRs per hill (Table 6). However, ratoon plants applied with combined organic and inorganic $\left(T_{3}\right)$ fertilizers and those applied with inorganic fertilizer $\left(T_{1}\right)$ alone showed similar response to those applied with purely organic fertilizer $\left(T_{2}\right)$ with 608 number of NRs per hill and 562.22 NRs per hill, respectively.

Table 5. Agronomic characteristics of the ratoon crop of lowland rice (PSB Rc82) as influenced by fertilization

\begin{tabular}{|c|c|c|c|c|c|}
\hline Treatment & $\begin{array}{l}\text { Days from } \\
\text { harvesting of } \\
\text { main crop to } \\
\text { maturity of } \\
\text { ratoon crop }\end{array}$ & $\begin{array}{l}\text { Plant Height } \\
\quad(\mathrm{cm})\end{array}$ & $\begin{array}{l}\text { Leaf Area } \\
\text { Index (LAI) }\end{array}$ & $\begin{array}{c}\text { Flagleaf } \\
\text { Length }(\mathrm{cm})\end{array}$ & $\begin{array}{l}\text { Straw Yield } \\
\left(\mathrm{t} \mathrm{ha}^{-1}\right)\end{array}$ \\
\hline $\begin{array}{l}\mathrm{T}_{0}-\mathrm{No} \\
\text { fertilization } \\
\text { (control) }\end{array}$ & $65.00 \mathrm{a}$ & 68.93 & 0.84 & 16.40 & 1.65 \\
\hline $\begin{array}{c}\mathrm{T}_{1}-45-30-30 \\
\mathrm{~kg} \mathrm{ha}^{-1} \mathrm{~N} \\
\mathrm{P}_{2} \mathrm{O}_{5}, \mathrm{~K}_{2} \mathrm{O}\end{array}$ & $58.00 \mathrm{~b}$ & 75.70 & 0.90 & 16.83 & 1.96 \\
\hline $\begin{array}{l}\mathrm{T}_{2}-5 \mathrm{t} \mathrm{ha}^{-1} \\
\text { Wellgrow }\end{array}$ & $58.00 \mathrm{~b}$ & 73.93 & 1.02 & 16.59 & 1.39 \\
\hline $\begin{array}{c}\mathrm{T}_{3}-22.5-15- \\
15 \mathrm{~kg} \mathrm{ha}^{-1} \mathrm{~N} \\
\mathrm{P}_{2} \mathrm{O}_{5}, \mathrm{~K}_{2} \mathrm{O}+ \\
2.5 \mathrm{tha}^{-1} \\
\text { Wellgrow }\end{array}$ & $58.00 \mathrm{~b}$ & 77.10 & 0.93 & 15.19 & 2.04 \\
\hline
\end{tabular}


Table 6. Root growth and development of the ratoon crop of lowland rice (NSIC Rc82) as influenced by fertilization

\begin{tabular}{|c|c|c|c|}
\hline Treatment & $\begin{array}{l}\text { Number of Nodal } \\
\text { Roots per hill }\end{array}$ & $\begin{array}{l}\text { Nodal Root Axis } \\
\text { Length }(\mathrm{cm})\end{array}$ & Root Length $(\mathrm{cm})$ \\
\hline $\begin{array}{c}T_{0}-\text { No fertilization } \\
\text { (control) }\end{array}$ & $420.78 b$ & 12.82 & 21.83 \\
\hline $\begin{array}{c}\mathrm{T}_{1}-90-60-60 \mathrm{~kg} \mathrm{ha}^{-1} \mathrm{~N} \\
\mathrm{P}_{2} \mathrm{O}_{5}, \mathrm{~K}_{2} \mathrm{O}\end{array}$ & $562.22 \mathrm{ab}$ & 13.57 & 25.45 \\
\hline $\mathrm{T}_{2}-5 \mathrm{t} \mathrm{ha}^{-1}$ Wellgrow & $677.55 a$ & 11.66 & 23.72 \\
\hline $\begin{array}{l}\mathrm{T}_{3}-45-30-30 \mathrm{~kg} \mathrm{ha}^{-1} \mathrm{~N} \\
\mathrm{P}_{2} \mathrm{O}_{5}, \mathrm{~K}_{2} \mathrm{O}+2.5 \mathrm{t} \mathrm{ha}^{-1} \\
\text { Wellgrow }\end{array}$ & $608.00 \mathrm{ab}$ & 10.80 & 22.95 \\
\hline
\end{tabular}

Table 7 presents the yield, yield components and harvest index $(\mathrm{HI})$ of ratoon crop of lowland rice as influenced by fertilization. Statistical analysis revealed that all yield and yield components as well as $\mathrm{HI}$ were not significantly affected by the fertilization treatments except for the yield component parameters such as the number of productive tillers per hill and the weight of 1,000 grains.

Ratoon plants applied with a combination of organic and inorganic fertilizers $\left(T_{3}\right)$ significantly produced higher number of productive tillers per hill (17.33) when compared to those unfertilized ratoon plants $\left(\mathrm{T}_{0}\right)$ and those applied with inorganic fertilizer $\left(T_{1}\right)$ alone with only 7.67 and 11.93 tillers per hill, respectively. Application of organic fertilizer $\left(T_{2}\right)$ also produced abundant productive tillers per hill of 16.10 . Oad et al (2002) revealed that tillering ability is the most important genetic factor affecting ratoon performance of grasses. Ratoon depends to a large extent on the inherent tillering capacity of a cultivar. They added that the application of nitrogen fertilizer is probably the most important nutrient management for improving the growth and yield of the ratoon crop of rice.

Regarding the weight of 1,000 grains, the ratoon crop applied with inorganic fertilizer $\left(T_{1}\right)$ markedly produced heavier weight of 1,000 grains with $25.67 \mathrm{~g}$ than the ratoon plants applied with pure organic fertilizer $\left(T_{2}\right)$ with only $23.67 \mathrm{~g}$. Application of both organic and inorganic fertilizers was comparable to the unfertilized plants $\left(T_{0}\right)$. Results of the study is attributed to the immediate effects of inorganic fertilizer application which probably enhanced the rapid translocation of nutrients to the growing spikelets and/or grains. 
Response of lowland rice

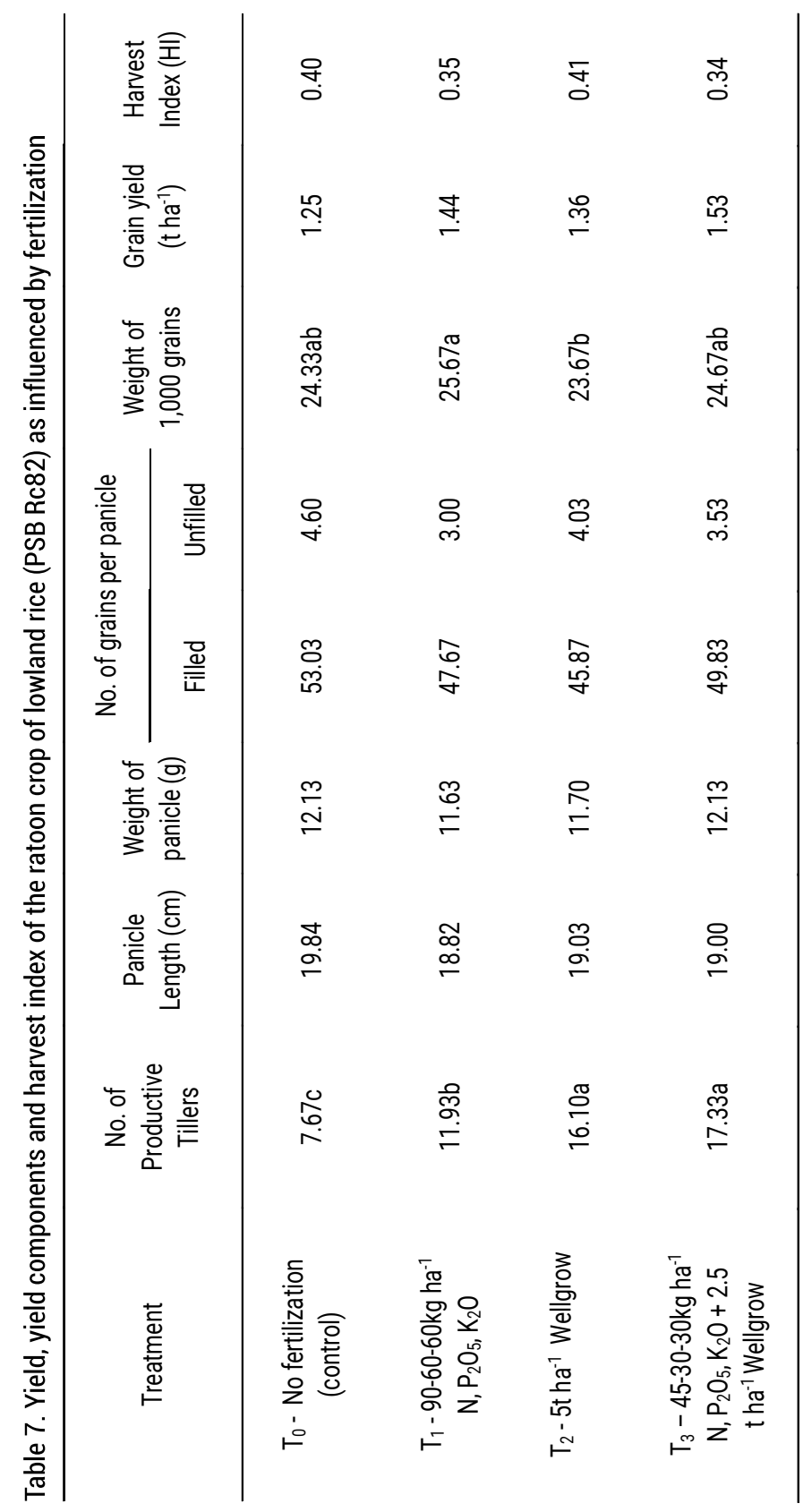




\section{Cost and Return Analysis}

The cost and return analysis of the main and ratoon crop of lowland rice PSB Rc82 as influenced by fertilization is presented in Table 8 . As can be seen, the main crop applied with inorganic fertilizer at the rate of 90-60-60kg ha-1 $N, \mathrm{P}_{2} \mathrm{O}_{5}, \mathrm{~K}_{2} \mathrm{O}\left(\mathrm{T}_{1}\right)$ generated the highest net income of PhP28,596 per hectare (exchange rate: 1 dollar $=51$ pesos). This was followed by the main crop applied with the combination of organic and inorganic fertilizers $\left(T_{3}\right)$ with a net income of PhP19,595.75. The lowest net income of PhP1,481.25 was obtained by the main crop applied with organic fertilizer $\left(\mathrm{T}_{2}\right)$ alone.

Table 8. Cost and return analysis per hectare of main and ratoon crop of lowland rice (PSB Rc82) as influenced by fertilization

\begin{tabular}{|c|c|c|c|c|}
\hline \multicolumn{5}{|c|}{ Main crop } \\
\hline Treatment & $\begin{array}{c}\text { Grain Yield } \\
\left(\mathrm{t} \mathrm{ha}^{-1}\right)\end{array}$ & $\begin{array}{c}\text { Gross Income } \\
(\mathrm{PhP})\end{array}$ & $\begin{array}{l}\text { Production } \\
\text { Cost }(\mathrm{PhP}) \\
\end{array}$ & $\begin{array}{l}\text { Net Income } \\
(\mathrm{PhP})\end{array}$ \\
\hline $\begin{array}{l}T_{0}-\text { No fertilization } \\
\text { (control) }\end{array}$ & 1.79 & 35,800 & $24,768.75$ & $11,031.25$ \\
\hline $\begin{array}{c}\mathrm{T}_{1}-90-60-60 \mathrm{~kg} \mathrm{ha}^{-1} \\
\mathrm{~N}, \mathrm{P}_{2} \mathrm{O}_{5}, \mathrm{~K}_{2} \mathrm{O}\end{array}$ & 3.52 & 70,400 & $41,804.00$ & $28,596.00$ \\
\hline$T_{2}-10 t_{\text {ha }}{ }^{-1}$ Wellgrow & 2.99 & 59,800 & $58,318.75$ & $1,481.25$ \\
\hline $\mathrm{T}_{3}-45-30-30 \mathrm{~kg} \mathrm{ha}^{-1}$ & & & & \\
\hline $\begin{array}{l}\mathrm{N}, \mathrm{P}_{2} \mathrm{O}_{5}, \mathrm{~K}_{2} \mathrm{O}+ \\
5 \mathrm{t} \mathrm{ha} \mathrm{a}^{-1} \text { Wellgrow }\end{array}$ & 3.09 & 61,800 & $42,204.25$ & $19,595.75$ \\
\hline \multicolumn{5}{|c|}{ Ratoon crop } \\
\hline $\begin{array}{l}\mathrm{T}_{0}-\text { No fertilization } \\
\text { (control) }\end{array}$ & 1.25 & 25,000 & $7,516.25$ & $17,483.75$ \\
\hline $\begin{array}{c}\mathrm{T}_{1}-45-30-30 \mathrm{~kg} \mathrm{ha}^{-1} \\
\mathrm{~N}, \mathrm{P}_{2} \mathrm{O}_{5}, \mathrm{~K}_{2} \mathrm{O}\end{array}$ & 1.44 & 28,800 & $13,718.00$ & $15,082.00$ \\
\hline $\mathrm{T}_{2}-5 \mathrm{t} \mathrm{ha} \mathrm{p}^{-1}$ Wellgrow & 1.36 & 27,200 & $22,750.00$ & $4,450.00$ \\
\hline $\begin{array}{l}\mathrm{T}_{3}-22.55-15-15 \\
\mathrm{Kg} \mathrm{ha}^{-1} \mathrm{~N}, \mathrm{P}_{2} \mathrm{O}_{5} \\
\mathrm{~K}_{2} \mathrm{O}+2.5 \mathrm{tha}^{-1} \\
\text { Wellgrow }\end{array}$ & 1.53 & 30,600 & $10,999.50$ & $19,600.50$ \\
\hline \multicolumn{5}{|c|}{ Main crop + Ratoon crop } \\
\hline $\begin{array}{l}\mathrm{T}_{0}-\text { No fertilization } \\
\text { (control) }\end{array}$ & 3.04 & 60,800 & $32,285.00$ & $28,515.00$ \\
\hline $\begin{array}{l}\mathrm{T}_{1}-90-60-60 \mathrm{~kg} \mathrm{ha}^{-1} \\
\mathrm{~N}, \mathrm{P}_{2} \mathrm{O}_{5}, \mathrm{~K}_{2} \mathrm{O} \\
\text { (Main crop) and } \\
\text { 45-30-30kg ha-1 } \\
\text { (Ratoon) }\end{array}$ & 4.96 & 99,200 & $55,522.00$ & $43,678.00$ \\
\hline $\begin{array}{l}\mathrm{T}_{2}-10 \text { tha- Wellgrow } \\
\text { (Main crop) and } \\
5 \mathrm{t} \mathrm{ha}^{-1} \text { Wellgrow } \\
\text { (Ratoon) }\end{array}$ & 4.35 & 87,000 & $81,068.75$ & $5,931.25$ \\
\hline $\begin{array}{l}\mathrm{T}_{3}-45-30-30 \mathrm{~kg} \mathrm{ha}^{-1} \mathrm{~N} \\
\mathrm{P}_{2} \mathrm{O}_{5}, \mathrm{~K}_{2} \mathrm{O}+5 \mathrm{tha}^{-1} \\
\text { (Main crop) and } 22.5- \\
\text { 15-15kg ha-1 }+2.5 \mathrm{tha}^{-1} \\
\text { (Ratoon) }\end{array}$ & 4.67 & 92,400 & $53,203.75$ & $39,196.25$ \\
\hline
\end{tabular}


Response of lowland rice

For the ratoon crop, only plants applied with both organic and inorganic fertilizers $\left(T_{3}\right)$ generated the highest net income of PhP19,600.50 while the lowest (PhP4,450.00) was obtained in treatments applied with pure organic fertilizer $\left(\mathrm{T}_{2}\right)$. Ratoon crops that received no fertilizer $\left(T_{0}\right)$ and those applied with inorganic fertilizer $\left(T_{1}\right)$ achieved positive net incomes of PhP17,483.75 and PhP15,082.00, respectively.

For the combined cost and return analysis of both main and ratoon crop, plants applied with inorganic fertilizer $\left(T_{1}\right)$ at the rate of $90-60-60 \mathrm{~kg} \mathrm{ha}^{-1} \mathrm{~N}, \mathrm{P}_{2} \mathrm{O}_{5}, \mathrm{~K}_{2} \mathrm{O}$ for the main crop and $45-30-30 \mathrm{~kg} \mathrm{ha}^{-1}$ of $\mathrm{N}, \mathrm{P}_{2} \mathrm{O}_{5}, \mathrm{~K}_{2} \mathrm{O}$ for the ratoon crop generated the highest net income of PhP43,678.00. Combined application of organic and inorganic fertilizers at the rates of $5 \mathrm{t} \mathrm{ha}^{-1}$ organic and half of the recommended inorganic fertilizer obtained a net income of PhP39,196.25. Unfertilized main and the ratoon crop $\left(T_{0}\right)$ and those applied with pure organic fertilizer $\left(T_{2}\right)$ also obtained positive net incomes of PhP28,515 and PhP5,931.25, respectively.

\section{CONCLUSIONS}

1. Application of inorganic fertilizers at the rates of $90-60-60$ and $45-30-30 \mathrm{~kg} \mathrm{ha}^{-1} \mathrm{~N}$, $\mathrm{P}_{2} \mathrm{O}_{5}, \mathrm{~K}_{2} \mathrm{O}$ for the main and ratoon crops, respectively, significantly increased the LAl, number of productive tillers, weight of panicle, number of filled grains, and grain yield.

2. The combined application of organic and inorganic fertilizers produced taller plants, heavier straw yield, abundant number of productive tillers, heavy panicle and more filled grains.

3. Plants applied with inorganic fertilizer at the rate of 90-60-60kg ha-1 $\mathrm{N}, \mathrm{P}_{2} \mathrm{O}_{5}, \mathrm{~K}_{2} \mathrm{O}$ for the main crop and $45-30-30 \mathrm{~kg} \mathrm{ha}^{-1}$ of $\mathrm{N}, \mathrm{P}_{2} \mathrm{O}_{5}, \mathrm{~K}_{2} \mathrm{O}$ for the ratoon crop resulted in the highest net income.

\section{ACKNOWLEDGEMENT}

The authors thank the Visayas State University through the office of the Vice President for Research \& Extension for funding support.

\section{REFERENCES}

Abe J, Songmuang P \& Harada J. 1995. Root Growth of Paddy Rice with Application of Organic Materials as Fertilizers in Thailand. Japan Agricultural Research Quarterly 29(2):77-82

Bahar FA and De Datta SK . 1977.Prospects of increasing tropical rice production through ratooning. Agronomy Journal 69: 536-540

Bañoc DM. 2000. Plastic response of crop root system under soil moisture stress conditions (PhD dissertation). Nagoya University, Japan

Baoy RR and Bañoc DM. 2017. Growth and Yield Performance of Inbred and Hybrid Varieties as Influenced by Combined Application of Organic and Inorganic Fertilizers

Bidwell RGS. 1974. Plant Physiology (pp643). McMillan Publ. Co. Inc. 866 Third Ave., New York, New York. 10022 
De Datta SK. 1981. Principles and Practices of Rice Production (pp320-321). International Rice Research Institute (IRRI), Los Baños, Laguna, Philippines.

Gomez AK. 1972. Techniques for field experiments with rice (pp670). International Rice Research Institute, Los Baños, Laguna, Philippines

Gomez KA and Gomez AA. 1976. Statistical Procedures for Agricultural Research (2nd edn) (pp680). John Wiley and Sons, New York, USA

International Soil Reference And Information Center (ISRIC). 1995. In Van Reuwijk LP (ed) Procedure for soil analysis (pp106). Wagenigen, the Netherlands

Javier EF and Espiritu AE. 2015. Long-term use of organic fertilizers in paddy soils. In 2015 National Rice R \& D Highlights. PhilRice. Science City of Muñoz, Nueva Ecija

Landon JR. 1991. Booker Tropical Soil Manual. A handbook for soil survey and agricultural land evaluation in the tropics and subtropics (pp474). Longman Scientific and Technical John Wiley and Sons, Inc. 605 Third Ave., New York, NY0158

Mareza E, Djafar ZR, Suwignyo RA \& Wijaya A. 2016. Rice ratoon yield response to main crops cutting height in tidal swamps using direct seeding system. Agrivita Journal of Agricultural Science 38:126-132

Nelson DW and Sommers LE. 1982. Methods of Soil Analysis, Part. American Society of Agronomy-Soil Science Society of America. 677 South Segoe Road, Madison, WI 53711, USA

Oad FC, Sta Cruz P, Memon M, Oad NL \& Zia-Ul-Hassan. 2002. Rice Ratooning Management. Pakistan Journal of Applied Sciences 2(1):29-35

Olsen S, Cole C, Waenabe F \& Dean L. 1954. Estimation of available phosphorus in soils by extraction with sodium bicarbonate. USDA Circular Nr 939, US Gov. Print Office, Washington DC

Olsen JR and Sommers LE. 1982. Phosphorus (pp403-430). In Page AL, Miller RH \& Keeny DR (eds) Method and Soil Analysis Part 2. Chemical and Microbiological Properties (pp680). American Society of Agronomy Inc. Madison Wisconsin, USA

Santos AB, Fageria NK \& Prabhu AS. 2011. Rice ratooning management practice for higher yields. Communication in Soil Science and Plant Analysis 34:881-918

Weerakon WMW, Maruyama A \& Ohba K. 2008. Impact of Humidity on Temperature-Induced Grain Sterility in Rice (Oryza sativa L.). Journal of Agronomy and Crop Science. https://doi.org/10.1111/j.1439037x.2008.00293.x

Yoshida S. 1981. Fundamentals of Crop Science (pp268). International Rice Research Institute, College of Agriculture, Los Baños, Laguna, Philippines 